NBER WORKING PAPER SERIES

\title{
GLOBAL TALENT FLOWS
}

\author{
Sari Pekkala Kerr \\ William Kerr \\ Çağlar Özden \\ Christopher Parsons \\ Working Paper 22715 \\ http://www.nber.org/papers/w22715
NATIONAL BUREAU OF ECONOMIC RESEARCH 1050 Massachusetts Avenue
Cambridge, MA 02138
October 2016

This paper is a draft for the Journal of Economic Perspectives. We thank the editors and staff of the Journal of Economic Perspectives for their very helpful comments and expert guidance. We are grateful to Zovanga Kone for his assistance with the data work. Our research has been generously supported by the Alfred P. Sloan Foundation, the Kauffman Foundation, the National Science Foundation, the Smith Richardson Foundation, and Harvard Business School. Özden acknowledges financial support from the Knowledge for Change Program and the Multidonor Trust Fund for Trade and Development of the World Bank. The findings, conclusions, and views expressed in this paper are entirely those of the authors. They should not be attributed to World Bank, its executive directors and the countries they represent. Sari Pekkala Kerr is Senior Research Scientist, Wellesley Centers for Women, Wellesley College, Wellesley, Massachusetts. William Kerr is MBA Class of 1975 Professor of Entrepreneurial Management, Harvard Business School, Boston, Massachusetts, and Faculty Research Associate, National Bureau of Economic Research, Cambridge, Massachusetts. Çaglar Özden is Lead Economist, World Bank Development Research Group, Washington, DC. Christopher Parsons is Assistant Professor of Economics, University of Western Australia, Perth, Australia, and Research Associate, International Migration Institute, University of Oxford, Oxford, United Kingdom.

NBER working papers are circulated for discussion and comment purposes. They have not been peer-reviewed or been subject to the review by the NBER Board of Directors that accompanies official NBER publications.

(C) 2016 by Sari Pekkala Kerr, William Kerr, Çağlar Özden, and Christopher Parsons. All rights reserved. Short sections of text, not to exceed two paragraphs, may be quoted without explicit permission provided that full credit, including $\odot$ notice, is given to the source. 
Global Talent Flows

Sari Pekkala Kerr, William Kerr, Çağlar Özden, and Christopher Parsons

NBER Working Paper No. 22715

October 2016

JEL No. F15,F22,J15,J31,J44,L14,L26,O31,O32,O33

\begin{abstract}
$\underline{\text { ABSTRACT }}$
The global distribution of talent is highly skewed and the resources available to countries to develop and utilize their best and brightest vary substantially. The migration of skilled workers across countries tilts the deck even further. Using newly available data, we first review the landscape of global talent mobility, which is both asymmetric and rising in importance. We next consider the determinants of global talent flows at the individual and firm levels and sketch some important implications. Third, we review the national gatekeepers for skilled migration and broad differences in approaches used to select migrants for admission. Looking forward, the capacity of people, firms, and countries to successfully navigate this tangled web of global talent will be critical to their success.

Sari Pekkala Kerr

Wellesley College

106 Central Street

Wellesley, MA 02481

skerr3@wellesley.edu

William Kerr

Harvard Business School

Rock Center 212

Soldiers Field

Boston, MA 02163

and NBER

wkerr@hbs.edu

Çağlar Özden

$1818 \mathrm{H}$ street NW

The World Bank

MC3-303 DECRG

Washington, DC 20433

cozden@worldbank.org

Christopher Parsons

Economics (UWA Business School)

The University of Western Australia (M251)

35 Stirling Highway

CRAWLEY WA 6009

Australia

christopher.parsons@uwa.edu.au
\end{abstract}




\section{Introduction}

Highly skilled workers play a central and starring role in today's knowledge economy. Talented individuals make exceptional direct contributions_-including breakthrough innovations and scientific discoveries — and coordinate and guide the actions of many others, propelling the knowledge frontier and spurring economic growth. In this process, the mobility of skilled workers becomes critical to enhancing productivity. Substantial attention has been paid to understanding the worldwide distribution of talent and how global migration flows further tilt the deck. Observed migration flows are the result of a complex tangle of multinational firms and other employers pursuing scarce talent, governments and other gatekeepers trying to manage these flows with policies, and individuals seeking their best options given the constraints imposed upon them.

We begin by sketching the landscape of global talent mobility. The number of migrants with a tertiary degree rose nearly 130 percent from 1990 to 2010, while low skilled (primary educated) migrants increased by only 40 percent during that time. A pattern is emerging in which these high-skilled migrants are departing from a broader range of countries and heading to a narrower range of countries-in particular, the United States, the United Kingdom, Canada, and Australia. The globalization of economic ties is also leading to a rise in shorter-term and circular migration patterns for skilled labor; for example, global companies often insist that their rising executives live and work in other countries for a meaningful portion of their careers. We also give examples showing how global migration may be most pronounced for those at the very outer tail of the talent distribution and that female high-skilled migration outnumbered males in 2010.

Next, we discuss the causes and consequences of high-skilled migration. We start with a basic model of the income incentives to migrate for different skill levels. We then expand the discussion to include important factors like advantages of agglomeration, productivity spillovers, intra-firm relocation of employees in multinationals, and how tertiary and graduate education abroad is linked to future job opportunities in other countries. These factors also suggest why high-skilled immigration is often controversial. For recipient countries, high-skilled immigration is often linked to clusters of technology and knowledge production that are certainly important for local economies and are plausibly important at the national level. More than half of the high-skilled technology workers and entrepreneurs in Silicon Valley are foreign-born. For native workers, high-skilled immigration means both greater competition for certain jobs, but also a chance to benefit from the complementarities and agglomeration effects created by talent clusters. For sending countries, the loss of high-skilled workers raises concerns over "brain drain." On the positive side, high-skilled emigrants can create badly needed connections to global sources of knowledge, capital, and goods - and some will eventually return home with higher social and human capital levels.

With these controversies and tensions in mind, we then review the "gatekeepers" for global talent flows. At the government level, we compare the points-based skilled migration regimes as historically implemented by Canada and Australia with the employment-based policies used in the United States through mechanisms like the $\mathrm{H}-1 \mathrm{~B}$ visa program. Because of the links of global migration flows to employment and higher education opportunities, firms and universities also act as important conduits, making employment and admission decisions that deeply affect the patterns of high-skilled mobility. There are ongoing efforts in many countries to tweak their immigration policies concerning high-skilled 
labor to tilt the social cost-benefit calculations in a more favorable direction. Looking forward, the capacity of people, employers and governments to successfully navigate this tangled web of global talent markets will be critical for their success.

\section{Trends in Global Talent Flows}

Approximately 3 percent of the world's population lives in a country different from that of their birth and, despite the impression sometimes presented in the media, this share has been roughly constant since 1960 (Özden et al. 2011). Beneath this stable overall level, however, global migration patterns have become increasingly asymmetric and skewed along several dimensions, especially as skilled migration has become a greater force globally.

Most of the data concerning high-skilled migration that we discuss here are taken from global bilateral migration database as described in Docquier et al. (2009), in addition to the recently completed update of the Database on Immigrants in OECD Countries (DIOC) for 2010 (Arslan et al. 2014). ${ }^{1}$ These databases report the stock of migrants by education level from each home country that have moved to each destination country. High-skilled workers, our main focus, are defined as those with at least one year of tertiary education. The data come from decennial national censuses conducted in 1990, 2000 and 2010 in the destination countries (where available) or from labor force surveys (when necessary). The data presented cover people of working age (25+) and are matched according to individual countries' definition of migration, which typically pertains to country of birth. ${ }^{2}$

Figure 1 compares migration to OECD countries along multiple dimensions. There were about 28 million high-skilled migrants residing in OECD countries in 2010, an increase of nearly 130 percent since 1990. By comparison, the growth rate for low-skilled migrants in the OECD countries from 1990 to 2010 was only 40 percent. (Throughout, we use the term 'low skill' to designate migrants with only primary education and 'other skill' to refer to those not classified as high-skilled.) While OECD countries constitute less than a fifth of the world's population, these countries host two-thirds of high-skilled migrants (OECD Factbook 2013; Artuç et al. 2015).

The exceptional rise in the number of high-skilled migrants to OECD countries is the result of several forces, including increased efforts to attract them by policymakers as they recognize the central role of human capital in economic growth, positive spillovers generated by skill agglomeration, declines in transportation and communication costs, and rising pursuit of foreign education by young people. Among the resulting effects are the doubling of the share of the tertiary-educated in the labor force and fierce competition among countries hoping to attract talent (for example, Kapur and McHale 2005; National

\footnotetext{
${ }^{1}$ The 2010 update was developed by the OECD, the World Bank and the International Migration Institute at Oxford University. The details of the databases, their construction, methodology and the main patterns are discussed in Arslan et al. (2014). There is a parallel DIOC-E database for non-OECD countries (http://www.oecd.org/els/mig/dioc.htm) described by Artuç et al. (2015).

${ }^{2}$ To achieve harmonized and comparable series over the 20-year period, we exclude Chile, Estonia, Israel, Slovenia, and South Korea from our analysis. Throughout this article, we use 'OECD' to refer to the 29 remaining members, irrespective of their date of joining the OECD.
} 
Academies 2016). While the migration of low-skilled workers mainly offsets the decline in low-skilled native workforces in advanced countries, high-skilled migration often complements the growth of skill levels for native workforces.

Even among OECD destinations, the distribution of talent remains skewed. Four Anglo-Saxon countries - the United States, the United Kingdom, Canada and Australia—constitute the destination for nearly 70 percent of high-skilled migrants (to the OECD) in 2010. The United States alone has historically hosted close to half of all high-skilled migrants to the OECD and one-third of high-skilled migrants worldwide. In 2010, the United States hosted 11.4 million skilled migrants, 41 percent of the OECD total. The attractiveness of English-speaking, high-income countries for high-skilled migrants has led other destination countries, such as France, Germany and Spain, to increase their efforts to attract these workers. Nevertheless, the volume of skilled migration to the four Anglo-Saxon countries, coupled with the significant asymmetry in the concentration of leading universities, high-tech firms and research centers, implies that the global competition for skills will continue to be fierce and will likely remain unequal.

Such stark inequalities in the concentrations of talent also exist across regions and cities within individual destination countries. In 2013, Southern California, Silicon Valley and New York City combined to host around one-eighth of total STEM employment (that is, jobs with a high component of science, technology, engineering and mathematics) in the United States (Silicon Valley Competitiveness and Innovation Report 2015). Moreover, 56 percent of STEM workers and 70 percent of software engineers in Silicon Valley in 2013 were foreign born. Elsewhere, Western Australia has the highest percentage of foreign-born medical practitioners at around 60 percent in 2011. London, New York, Paris, and Milan continue to maintain their positions as the global capitals of finance as well as fashion.

Agglomeration can be even starker in the upper tail of the talent distribution (Stephan and Levin 2001; Wasmer et al. 2007; Stephan 2010; Weinberg 2011). Trends in the awarding of the Nobel Prizes for Chemistry, Medicine, Economics and Physics, where an institutional affiliation can be assigned with certainty, illustrate particular broad patterns. Since 1901, individuals affiliated with institutions in four countries - the United States (330 individuals), the United Kingdom (90), Germany (69) and France (33) - have been awarded over 80 percent of these Nobel Prizes. ${ }^{3}$ The US domination of these awards is fueled in large part by emigration of prominent scientists. In the first third of the time period since 1901, 9 percent of these Nobel Prize winners were born in the United States and 13 percent were affiliated with US institutions at the time of their winning. In the most recent third of the time period, however, academics associated with American institutions have won over 65 percent of these Nobel Prizes, yet only 46 percent of this group was born in the United States. Of all Nobel Prizes across the four subject areas, 31 percent (203 of 661) have been awarded to immigrants, of whom 53 percent (107 of 203) were affiliated with American institutions. The asymmetry of the flows is remarkable. Only four Americans were affiliated with non-American institutions when they received the award, out of 230 total Nobel

\footnotetext{
${ }^{3}$ Data for Nobel prizes is derived from https://www.aggdata.com/awards/nobel prize winners, supplemented with data from the Nobel Prize website for the years 2011-2015.
} 
Prizes being awarded to Americans. Even among advanced economies, the most elite researchers are often clustered in very select locations. ${ }^{4}$

Figure 1 shows that these observations are indicative of wider trends. OECD countries continue to attract larger numbers of high-skilled migrants, particularly from non-OECD countries. While high-skilled migration within OECD countries rose 68 percent to 10.2 million between 1990 and 2010, the total number of high-skilled migrants from non-OECD countries increased 185\%, from 6.2 million to 17.6 million. This pattern is also evident in the extreme cases of sending countries. For the two decades prior to 2010, the United Kingdom was the largest origin country in terms of numbers of outbound skilled migrants. It was supplanted in 2010 by India (2.1 million) and the Philippines (1.5 million), while China (1.4 million) also had high absolute numbers of high-skilled emigrants. In terms of the greatest increases over time (and considering only those large countries that sent at least 25,000 highly skilled workers abroad), Algeria (a rise of 954 percent), Russia (910 percent), Bangladesh (459 percent), Romania (428 percent), Venezuela (423 percent), Ukraine (385 percent), Pakistan (380 percent) and India (370 percent) showed the greatest increases in high-skilled emigration between 1990 and 2010.

A remarkable and underappreciated component of this high-skilled migration surge is the role of females. Figure 1 shows that the stock of high-skilled female immigrants in OECD countries grew by 152 percent between 1990 and 2010, from 5.7 to 14.4 million. Indeed, in 2010, the stock of high-skilled female migrants surpassed the stock of high-skilled male migrants. The root causes of this surge have yet to be traced out fully. Africa and Asia experienced the largest growth of high-skilled female emigration, indicating the potential role of gender inequalities and labor market challenges in origin countries as push factors. Evidence is accumulating that differences between origin and destination countries in women's rights underpin such flows (Nejad and Young 2014). The simple correlation between the growth in highskilled female migration and the UNDP Gender Inequality Index is 0.43.

More broadly, research needs to trace out many features like the detailed occupational distribution of female immigrants. The available data highlight some interesting early patterns. In 2010, of the 4.2 million employed high-skilled females in the United States, 16 percent were employed as Healthcare Practitioners and Technical Occupations, 13 percent in Office and Administrative Support Occupations and 12 percent in Education, Training, and Library Occupations. These constituted 66, 68 and 63 percent of the total high-skilled immigrants in these occupations, respectively. Notably, while only 3 percent of high-skilled females were employed in Healthcare Support Occupations, they represented no less than $80 \%$ of foreign-born workers in these jobs. Interestingly, the OECD reports that some 37 percent of highskilled females in the United States were employed in occupations in 2010 that were not commensurate with their level of education. ${ }^{5}$ Given the rising prominence of high-skilled females, this is an important

\footnotetext{
"As a second example from our profession, the John Bates Clark Medal is awarded annually to a top "American" economist under the age of forty. Four of its nine winners since 2005 were born outside of the United States. ${ }^{5}$ Across Canada in the same year, observed patterns are comparable. In terms of occupations, 10 percent of highskilled females worked as Teaching Professionals, 10 percent as Business and Administration Associate Professionals, 8 percent as Health Professionals, and 8 percent as Business and Administration Professionals. While only 4 and 7 percent of high-skilled females were employed as Health Associate Professionals and Personal Care Workers respectively, these represented 73 and 90 percent of the total foreign born working in these occupations.
} 
avenue of future research. It will also be important to trace whether the extreme tail of the female talent distribution displays the same migration propensities as those documented for males.

Another important shift since 1990 is that OECD countries increasingly attract high-skilled migrants from a wider set of origin countries. Figure 2 summarizes this pattern by displaying cumulative distributions for high-skilled immigration and emigration stocks in 2010. The line at the top left of the graph shows the immigration distribution of high-skilled workers. We rank destination countries according to the stock of immigrants they attract, and we tabulate the cumulative share as we add more countries. This line starts at almost 40 percent, as the United States is the first-ranked country and accounts for the largest share of global immigration flows. As noted earlier, further adding the United Kingdom, Canada, and Australia pushes the cumulative share to almost 75 percent. The second line graphs the equivalent distribution for emigration of high-skilled workers, with countries now ranked by how many migrants they send abroad. The gap between the two lines clearly shows that skilled emigration originates from many countries, even if it flows to relatively few. By contrast, low-skilled immigrants in OECD countries are increasingly arriving from fewer origin countries.

Many origin countries have limited educational capacities and fiscal resources to train workers or to replace those that have emigrated. Countries experiencing particularly high emigration rates of highskilled workers to OECD destinations in 2010 tend to be small low-income countries and island states, such as Guyana (93 percent), Trinidad and Tobago (68 percent), Barbados (66 percent), Tonga (53 percent), and Zimbabwe (44 percent). Figure 3 demonstrates this inverse relationship between country size and high-skilled emigration rates. Emigration rates are also decreasing in GDP per capita, and these patterns are much starker for high-skilled migration than for overall flows. These movements of highskilled labor away from certain small and low-income countries have raised controversies about "brain drain”- a topic to which we will return when considering implications of these talent flows.

A natural consequence of these patterns is that host countries may end up with high concentrations of high-skilled immigrants in particular occupations. For example, immigrants account for some 57 percent of scientists residing in Switzerland, 45 percent in Australia, and 38 percent in the United States (Franzoni et al. 2012). In the United States, 27 percent of all physicians and surgeons and over 35 percent of current medical residents were foreign born in 2010. Immigrants also accounted for over 35 percent of recent enrollments in STEM fields, with very high proportions in specific areas like Electrical Engineering (70 percent), Computer Science (63 percent) and Economics (55 percent) reported by Anderson (2013). In the United Kingdom in 2014, the Guardian newspaper reported that the National Health Service (NHS), the world's fifth largest employer, employed workers from some 200 countries worldwide and 26 percent of NHS doctors were not originally British citizens. ${ }^{6}$

The global migration of inventors and the resulting concentration in a handful of countries have been particularly well documented. Kerr (2016) reviews the literature and we focus here on patent records taken from the World Intellectual Property Organization (WIPO) database. Miguelez and Fink (2013)

38 percent of high-skilled females in Canada were employed in occupations in 2010 that were not commensurate with their level of education.

${ }^{6}$ https://www.theguardian.com/society/2014/jan/26/nhs-foreign-nationals-immigration-health-service. 
calculate that the global migration rate of inventors in 2000 stood at 8.6 percent, at least 50 percent greater in share terms than the average for high-skilled workers as a whole. Figure 4 builds on WIPO global patent filings from 2001-2010. The United States has received an enormous net surplus of inventors from abroad, while China and India have been major source countries. Some countries like Canada and the United Kingdom are major destinations but still experience a negative net flow due to even larger emigration rates for inventors, usually to the United States.

Similarly striking levels of immigrant concentration are evident in sports, where global outliers in terms of talent and income are the norm. Spectators in the English Premier League, the most popular and profitable soccer league in the world, have now witnessed the fielding of players from 100 different nationalities during the 2013-14 season. As of 2015, the English Premier League featured more players of different nationalities than any other league in Europe, followed by Germany's Bundesliga (55 nationalities), Italy's Serie A (51), Spain's La Liga (50) and France's Ligue 1 (48). The highest-quality players in the world are typically concentrated in the top teams within the top flights, suggestive of increasing returns and productivity spillovers. ${ }^{7}$ This pattern is similar to top academic departments where we observe above-average diversity, when compared to other employers. Furthermore, these patterns have long-term implications. Both soccer clubs and academic departments train the next generation of players/academics, leading to further agglomeration within the upper tail and reinforcing existing distributional patterns and inequalities. We turn next to the factors behind these migration flows.

\section{Drivers and Consequences of Skilled Migration}

The core theoretical framework for studying human capital flows dates back to at least John Hicks (1932), who noted that "differences in net economic advantages, chiefly differences in wages, are the main causes of migration.” The standard textbook model (Borjas 1987, 2012) used to explain the self-selection of immigrants by skill level is typically built on the Roy (1951) model. One can explain certain aspects of current high-skilled migration patterns using this model. For example, the United States has a very wide earnings distribution and low tax levels and progressivity, especially compared to most source countries, including many high-income European countries. As a result, we can see why the United States would attract more high-skilled migrants, relative to low-skilled migrants and relative to other high-income countries. It is also clear within this framework why demand for migration from developing economies is substantial, as their wage levels sit completely below those in advanced countries at all skill levels.

A more complete explanation of the causes and consequences of migration patterns of high-skilled labor requires adding multiple ingredients beyond the textbook model. Key factors include the importance of

\footnotetext{
${ }^{7}$ Simply put, Neymar's productivity would probably be significantly lower without Messi or Suarez! One author of this piece confesses to not understanding one word of the football (soccer!) analogy. American readers may find it useful to consider the overwhelming concentration of basketball and hockey talent in US-centered leagues. In 2016, every team in the National Basketball Association had at least one player born outside of America. Since 1991, international players in the NBA have increased four-fold to over 100 and were drawn from 37 countries in the $2014-15$ season.
} 
location, which in turn reflects institutional and educational differences across countries, productivity spillovers, agglomeration effects and how both workers and employers interact with these differences.

Geographic locations provide different levels of access to financial and physical capital, technology, complementary institutions and workers, which all impact the quality and productivity of the available jobs (Moretti 2012). Moreover, many high-skilled occupations show agglomeration effects, where an individual worker's productivity is enhanced by being near to or working with many other skilled workers in similar sectors or occupations. Indeed, in the presence of agglomeration effects, high-skilled migration need not diminish the returns to skills. In fact, due to agglomeration effects, a surge of high-skilled migration increases the incentive for other high-skilled workers to migrate to the same location. In the simplest terms, the huge concentration of actors and actresses in Hollywood only heightens the migration of aspiring talent to it, especially for the very talented.

At the core of this clustering process is trade in products and services. Continuing with the last example, Hollywood studios compete with each other globally; their market is not limited to Southern California. This is quite different than neighboring supermarkets, for example, which compete for the same local consumer base. Thus, there is no inherent limit as to how many studios can physically exist in Hollywood. On the contrary, new migrants encourage the employment of others through establishing new studios or expanding existing production. Furthermore, thick local markets for skilled labor can allow specialization that helps Hollywood studios compete better globally. High-skilled immigrants like Christian Bale, Audrey Hepburn or Natalie Portman allow native actresses and actors to specialize and become more productive, creating better products for worldwide consumption. Moreover, the agglomeration of activity in a specific location allows larger scale for complementary specialized inputs and providers such as legal counsels, voice trainers and costume makers.

Another issue is that a substantial share of high-skilled migration is connected, at least initially, to differences in educational opportunities. Many "skilled immigrants" arrive with only raw talent and ambition, with the aim of improving their human capital level through formal schooling or by learning on the job. This is clearly a factor in the prominence of the four leading Anglo-Saxon countries as destinations. These four countries host 18 of the top 20 and 69 of the top 100 universities globally, as ranked by Academic Ranking of World Universities (the 2016 rankings are available at http://www.shanghairanking.com/ARWU2016.html). ${ }^{8}$

Moreover, schooling can provide an important entry point into desired labor markets for talented individuals (Rosenzweig 2006; Grogger and Hanson 2013). Kato and Sparber (2013) show how declines in the availability of high-skilled visas made American universities less attractive to foreign students, in

\footnotetext{
${ }^{8}$ Interestingly, different types of graduate education display varying geographic concentrations. A recent Financial Times ranking of business schools included institutions from nine countries among the top 30 schools, with only 14 of the top 30 programs in the United States. Even among the top 15 business schools, seven countries are represented (http://rankings.ft.com/businessschoolrankings/global-mba-ranking-2016). By contrast, the ranking of Amir and Knauff (2008) for economics PhD programs features only four countries, with the United States accounting for 24 of the top 30 departments and the United Kingdom accounting for an additional four programs. These rankings use different methodologies, so the comparisons are not precise, but the stark differences are worthy of further study.
} 
terms of the number of foreign applicants and also the quality of those applicants as measured by SAT scores, compared to a handful of sending countries that were not impacted by the policy shift. Similarly, foreign students, mostly from East and South Asian countries, make up almost a quarter of the student population in Australian universities and easier entry into the Australian labor market is often cited as one of the key factors in their location choices. At later points in the educational process, Bound et al. (2015b) describe the use of graduate education in US universities to obtain access to the US labor market, and also the buffer that additional education can provide until a labor market match is realized. ${ }^{9}$

Even when a labor market match occurs for skilled migrants, there is a substantial possibility of return migration-although the rate seems to vary across skill sub-groups. The data on the subject remain limited with OECD (2008) representing an extensive effort to compile the currently available information. This report shows that 20-50 percent of immigrants leave within five years of arriving, depending on the corridor and the time period. These levels are consistent with historical patterns; for example, Bandiera et al. (2013) find that over half of the migrants who came to the United States during the age of mass migration in the late $19^{\text {th }}$ century returned home. Another common yet overlooked pattern is transit migration where migrants move from one destination to another. For example, close to 15 percent of the high-skilled migrants in the United States actually arrived from a country different than their place of birth (Artuç and Özden 2016). This is especially common among migrants from developing countries who face high entry restrictions to the United States. In order to circumvent these policy barriers, they migrate to countries like the United Kingdom (for South Asian migrants) or Australia (for East Asians) and then move to the United States.

In some settings, high-skilled immigrants have been found to be more likely to return home than lowskilled migrants (Bijwaard and Wahba 2014). ${ }^{10}$ Immigrants who decide to return to their home country tend to do so within a reasonably short time period (OECD 2008), and the likelihood to return has been connected to economic conditions (for example, Bijwaard et al. 2014), the difficulty of obtaining permanent residency or citizenship, and the ease of moving across national borders (Gundel and Peters 2008). Another pattern is that the relationship between return and skill levels is non-monotonic. While high-skilled workers are more likely to re-migrate as a group, those at the very highest skill levels are often less likely to do so. For example, the OECD (2008) calculates that the United States retains about

\footnotetext{
${ }^{9}$ These channels are, of course, tightly connected and build upon each other. Exceptional students are attracted to the frontier of knowledge creation, where they can themselves contribute throughout their careers to further innovations within and outside of academia. Even if pursuing purely commercial activities, these migrants can continue to promote the system through tax revenues, creating robust labor markets for graduating students. If a location starts to lose its frontier advantages, however, it may then become less attractive to future generations, which in turn further distances it from other attractive choices.

${ }^{10}$ Germany loses about 50 percent and Netherlands as many as 60 percent of foreign students coming to complete a degree within five years of graduation (Bijwaard 2010). Gundel and Peters (2008) find that high-skilled immigrants are more likely to re-emigrate from Germany. Pohl (2006) argues that a large share of high-skilled migrants exhibits short staying patterns, but once controlling for a number of other factors the average high-skilled migrant is actually less likely to leave. Dustmann and Weiss (2007) use the British household panel and find that outmigration causes the remaining immigrant pool in the United Kingdom to become less skilled over time. In Canada, all immigrant groups display high re-emigration rates, but those arriving in the skilled class and business class were most likely to leave again (Aydemir and Robinson, 2008). Dustmann et al. (1996) review policies related to return migration in Europe.
} 
65-70 percent of those who studied for a doctorate at the five-year mark after receipt of degree, higher than university graduates. Several comparative studies show in diverse settings that those with a PhD or high productivity levels are less likely to return migrate than other skilled workers (Finn 2007; Gibson and McKenzie 2009; Harvey 2009; Gaule 2014).

Another factor driving skilled labor migration is that many multinational companies require their executives to work in overseas positions as a prerequisite for senior leadership positions, in part because global opportunities account for the majority of such firms' long-term growth (Kerr et al. 2015a). The scale and growth of workforces within multinational firms are often underappreciated in the migration literature. Global companies like IBM, General Electric, and Siemens, however, usually have at least half of their workforce employed outside of their headquarter country. Prominent firms with immigrant chief executive officers are not limited to high-tech (such as Google and Microsoft) but include many traditional firms such as Alcoa, Clorox, Coca-Cola, Dow Chemical, McDonalds, Pepsi and Pfizer. While unskilled workers are often drawn from the local labor forces within the country of operation, high-skilled staff and especially senior managers are frequently transferred within the firm throughout their careers. In other cases, many large high-tech companies send recruiting teams to engineering schools in India and other developing countries. Given the large absolute numbers of students that are graduating abroad in countries like China and India (Freeman and Huang 2015), this traditional flow is quite likely to continue for some time.

One tangible outcome of this process is the rise of global collaborative teams for inventive work (Miguelez 2016; Kerr and Kerr 2015), which is well documented in patent filings and thus provides a source of data for studying certain effects of migration. For example, Branstetter, Li and Veloso (2015) document that the majority of China's patents filed with the US Patent and Trademark Office come from multinational firms expanding into China and often taking US-based inventors along to facilitate the entry. Foley and Kerr (2013) more broadly show how the ethnic composition of US multinational firms can shape their foreign investment activity. This builds on earlier work concerning business networks and skilled migration (for example, Docquier and Lodigiani 2010; Kugler and Rapoport 2011), and Hovhannisyan and Keller (2015) relatedly connect high-frequency business travel to innovation outcomes.

\section{Some Implications}

Global integration is generating ever-greater returns for matching talent with the right job or opportunity. The implications of these global talent flows are profound, touching everything from business to politics, to religion to culture to entertainment. From this sea of potential topics, we briefly discuss a few insights with implications for understanding the role of immigration policy and the future patterns of high-skilled migration. Kerr (2016) provides a longer review and more references for the issues highlighted below.

First, recent work confirms the importance of location for enhancing the productivity of skilled migrants (for example, Clemens 2013; Kahn and MacGarvie 2016), which is a critical first step towards connecting talent flows to higher worldwide productivities. Researchers are beginning to trace some of the details and nuances of how this occurs. With Fulbright scholars, for example, the productivity differences of 
individuals are mainly between advanced and developing economies, versus differences between the United States and other advanced economies. In other settings, the importance of location becomes more acute. More than half of the entrepreneurs in Silicon Valley are immigrants, and their productivity in global entrepreneurship depends upon the narrower geographic network to which they belong. The European Union offers a case study that should be a fruitful subject for research, given that it has removed restrictions on internal migrant flows imposed by individual countries. And Brexit potentially offers a case study in the opposing direction.

Second, a substantial avenue of recent research has focused on the extent of the net innovation and productivity gains realized in receiving countries from the talent inflows, with the United States being the most studied case. This work is often framed in the themes of endogenous growth literature similar to Jones (1995). The empirical evidence remains debated. Studies exploiting long-horizon and spatial variation in high-skilled immigration often find results consistent with immigrants boosting innovation and productivity outcomes. ${ }^{11}$ Conversely, other studies suggest immigrants mostly displace natives to yield a zero net benefit. ${ }^{12}$ Outside of the United States, positive net impacts are observed in several European countries for national diversity on innovation. ${ }^{13}$ Our perspective is that the weight of the evidence points to high-skilled immigrants boosting innovation and productivity - mainly through the increased quantity of skilled individuals pursuing innovative work-and we are sure this debate will persist for some time.

Researchers, following studies like Peri and Sparber (2011), are now developing a deeper understanding of the types of skills that port well across countries (such as STEM, computer programming, and academic research) and the underlying traits of these skills (such as weaker dependence on local culture and language, limited returns to local experience). Developing this granularity has helped researchers better identify and interpret wage and employment implications of high-skill mobility on native workers. To illustrate, imagine a scenario in which high-skilled migration pushes American engineers to leave their occupations. Instead, those Americans move to marketing, where they receive a substantially higher wage and, more importantly, they work together with the migrant engineers. Does this scenario present the negative consequences of migration, with Americans crowded out of engineering jobs? Is it a story of a positive complementarity, in which migration allows immigrants and natives to specialize in occupations based on their comparative advantages and increase their joint productivity? Or perhaps without the presence of foreign engineers, the engineering work would have shifted abroad and Americans would have moved to marketing anyway, but perhaps would be less productive due to geographic distance from the engineering staff now abroad? These implications are not easy to assign and will be a focus of impactful research ahead.

Finally, skilled migrants serve as effective conduits for many forms of multi-directional exchange in a networked world: trade, foreign direct investment, finance, knowledge, technology, cultural norms and political views (for example, Parsons and Winters 2014; Saxenian 2002, 2006). Terms like “brain drain”

\footnotetext{
${ }^{11}$ For example, Hunt and Gauthier-Loiselle 2010; Kerr and Lincoln 2010; Stuen et al. 2012; Moser et al. 2014; Kerr et al. 2015b; Peri et al. 2015; Ghosh et al. 2016.

${ }^{12}$ For example, Matloff 2003; Hira 2010; Borjas and Doran 2012; Doran et al. 2014; Bound et al. 2015a.

${ }^{13}$ For example, Ozgen et al. 2011; Bosetti et al. 2013; Parrotta et al. 2014; Breschi et al. 2014, 2015; Nathan 2015.
} 
and "brain gain" are now used to label settings where the gains to the sending country from migration fall short of or exceed the costs (for a review, see Docquier and Rapoport 2012). With respect to productivity development, analyses like Kerr (2008) and Agrawal et al. (2011) document that countries gain access to technical information from their overseas community, but there is substantial heterogeneity in the strength of these connections and the types of transfers facilitated. Thus, there is no one-size-fits-all answer here. Moreover, to develop informed cost-benefit analyses, we need much greater insights into where migrating individuals were trained, who funded the training, what other opportunities looked like (for example, Bhagwati 1976; Beine et al. 2007; Özden and Phillips 2015), and the full range of multidimensional exchanges that are facilitated.

\section{Policies and Gatekeepers}

A wide array of factors leads countries to restrict migration, including political, cultural and even philosophical motivations. One might question why high-skilled migration should ever be restricted, even if there are justifications for broader regulations of low-skilled flows (for example, Clemens 2011). The primary economic arguments in favor of restrictions on high-skilled migration center on possible adverse wage and employment effects on skilled native workers, as argued in Borjas and Doran (2012), Doran et al. (2014) and Bound et al. (2015a). Another argument is that governments may want to limit the volatility of migration flows that might accompany and possibly amplify ups and downs of the cyclical labor markets characterized by technology booms and busts. Finally, national security concerns are proposed as reasons to restrict the employment of high-skilled immigrants in certain key industries or with certain sensitive technologies.

Advocates for flexible migration policies for high-skilled labor alternatively point to how skilled immigrants can benefit native workers through complementary skills, through the agglomeration effects generated by a dense cluster of skilled workers, or through the labor demand that results from immigrant entrepreneurship and innovation. These views are as passionately held as those who argue against immigration, and many advocates of greater skilled migration to the United States have adopted the phrase "national suicide" to characterize the current US restrictions on skilled inflows. More broadly, fostering and strengthening skilled immigration is often a prominent pillar in the economic development strategies of countries. In the 2013 World Population Policies report, 40 percent of countries reported policies to raise immigration of high-skilled workers, a large increase from 22 percent in 2005.

There are two broad policy approaches used by countries to select high-skilled individuals, although as we discuss later, most countries display elements of both. The first approach is points or merit based and is often referred to as supply-side policies to migration, since it focuses on screening of individual applicants for admission. The second conceptual model is an employer-driven system. This is also described as a demand-side approach since it places emphasis on firms selecting skilled workers to admit into the country.

Canada and Australia are prominent examples of countries that implement points-based systems for skilled migration. These programs select individuals based upon their observable education, language skills, work experience, and existing employment arrangements. Each factor is weighted by a formula and 
online calculators often help migrants evaluate their characteristics for seeking a skilled work visa. ${ }^{14}$ In the Canadian example, migrants need to collect 67 points across six categories. In terms of education, for example, 15 points are awarded for one-year post-secondary diploma, trade certificate or apprenticeship, compared to 25 for a doctorate degree. With regards work experience, six or more years of applicable experience receive 15 points, compared to 9 points for just one year of experience.

The points-based approach offers an explicit statement of migration priorities for public debate thereby generally leading to stable immigration processes over time. Yet it also has certain disadvantages. Establishing and adjusting an optimal weighting scheme over time is hard and multi-year queues for applicants are possible. The screening process needs to catch migrants who are exaggerating or misrepresenting their qualifications, and there is some scope for adverse selection if those with few other migration options are otherwise attracted. Talented migrants may also find themselves underemployed after their arrival due to lack of demand for their skills, with the typical anecdote being a nuclear physicist who is driving a taxi due to lack of better opportunities. It could be argued that the underemployed migrant is still better off, as revealed by their continued stay in the host country; however, this underemployment often indicates the country did not realize the benefits of migration it sought. There may be public sector costs of the migration (for example, schooling of children) that are not covered by the tax receipts generated, and employers would have preferred someone further back in the queue.

The United States is the most cited example of a country that uses an employer-driven program for highskilled immigration, with the H-1B and L1 visas as primary categories (Kerr et al. 2015a). The H-1B visa allows US companies to temporarily employ skilled foreigners in "specialty occupations," defined to be those demanding application of specialized knowledge like engineering or accounting. The visas are popular in part due to their "dual intent" feature, which allows for the firm to also petition for permanent residency on behalf of the worker. Virtually all H-1B holders have a bachelor's degree or higher and about $70 \%$ of the visas in recent years went to STEM-related occupations. India is by far the largest source country, accounting for about two-thirds of $\mathrm{H}-1 \mathrm{~B}$ recipients in recent years. Visas are valid for three years and can be renewed once. Since 2004, the cap on new visa issuances has been 85,000, with 20,000 of these reserved specifically for advanced degree holders. Inclusive of renewals, 117 thousand $\mathrm{H}$ 1B visas were issued in fiscal year 2015 on a "first come, first served" basis. To protect domestic workers, firms are required to pay the visa holder the higher of the prevailing wage in the firm for the position, or the prevailing wage for the occupation in the area of employment. The mean annual starting compensation for a new H-1B worker was $\$ 75,000$ in $2014 .{ }^{15}$

The L1 visa allows temporary migration of employees of an international company with offices in both the United States and abroad. The migrant must have worked for the company abroad for at least one of the previous three years before coming to the United States. The duration of these visas is set on a

\footnotetext{
${ }^{14}$ For Canada, it is described at http://www.immigration.ca/index.php/en/who-qualifies-for-canadianimmigration-under-the-skilled-worker-program.

${ }^{15}$ Universities and colleges are the other important gatekeepers through their selection of individuals for the F1 (student) or J1 (exchange visitor) visas. Inclusive of renewals, 385 and 321 thousand F1 and J1 visas were issued in fiscal year 2015, respectively. While these visas do not offer long-term employment, US firms often recruit graduates of US schools using visas like the H-1B. 45 percent of new H-1B visas in fiscal year 2014 went to applicants already present in the US, which includes school-to-work transitions.
} 
bilateral and reciprocal basis with foreign countries, with renewals and extensions allowing a maximum stay of seven years. The L1 visa also allows dual intent application for a green card. Inclusive of renewals, 75 thousand L1 visas were issued in fiscal year 2015. As a third category, O1 visas for migrants with recognized extraordinary ability numbered about 9 thousand for fiscal year 2015. There are no specific numerical limits for these categories.

In employment-based regimes, labor markets, via employers, play a more direct role in determining the level and composition of skilled migration flows. A distinct advantage of this approach relative to the points-based approach is that employers choose whom they want and immigrants have a job upon arrival. This employer-employee match is guaranteed to connect the immigrant talent with a productive and commensurate job. Perhaps the largest liability of a quota-based program is its inherent potential to limit employers in the productive uses that they can make of talent workers. If the quota is set too low and agglomeration economies are strong, constrained employers will not be able to hire the foreign talent they desire and this will lower productivity growth and concomitant demand for native workers. In some years, including fiscal year 2016, applications for H-1B visas outstrip the available annual quota within a couple of days of the opening of the process.

More broadly, the centrality of employers in this approach can lead to certain disadvantages. First, firms may use the program for purposes that are not in line with the intentions of the government. For example, US policymakers intended the H-1B program to be used by companies to find workers for specific highskilled jobs. Yet a large share of H-1B visas in the past decade have been granted to Indian outsourcing firms that have realized the program can be used to temporarily bring their workers from India to the United States. This was not the goal of the program! Independent of the impacts of outsourcing, this diversion makes it more likely the program will find itself constrained for its original intent. Second, demand for visas under the employer-driven programs can show high volatility. For example, the share of $\mathrm{H}-1 \mathrm{~B}$ visas going to computer-related occupations has fluctuated between 25 and 80 percent over the course of a few years during the last two decades. While this volatility signals the responsiveness of the program to underlying labor market conditions, one can also imagine negative consequences, such as taking the steam out of the job market for recent college graduates who have invested several years in a field of study that was hot earlier. Third, unlike points-based programs, the migrant in an employmentdriven system is more tied to the sponsoring firm, at least for a period of time, and may be in a weak negotiating position, similar to a modern day "indentured servant."

Overall, the features of the two systems do not yield a clear absolute winner, and most real-world regimes combine different features of points-based and employment-driven systems. Superstar talent rarely competes for $\mathrm{H}-1 \mathrm{~B}$ visas, for example, but instead gains direct access to the United States through O1 temporary visas for extraordinary ability and direct green card applications of the EB-1 level for those with even more exceptional talent. Both of these categories are always in surplus. In effect, the US operates a points system for individuals with truly exceptional talents such as Nobel Prize winners, superstar athletes and musicians (Rosen 1981). Coming from the other direction, countries with pointsbased approaches have added weights to whether the applicant has a verified job and developed two-step processes that include points-based screening followed by sponsorship roles. Broadly speaking, it appears the overall shift is towards demand-driven elements and away from pure points-based programs (National Academies 2016), thereby prioritizing migrants' employability over a more flexible notion of human capital. In a rare cross-country comparison, Czaika and Parsons (2015) find evidence in favor of the 
efficiency of supply-driven criteria, and future research should further quantify the impacts of these policy design choices.

Moreover, it's important to remember that while there are important de jure differences in policies regarding high-skilled immigration, de facto differences in implementation or outcome may be much smaller. Many talented and motivated individuals often find their way to the countries they want to move to, even if it means marrying an American (two authors of this paper possibly offering an example!). Immigration systems are quite complex, with rules on admissions for temporary migration, selections for permanent residency and ultimately citizenship pathways impacting skilled worker choices. The United States, for example, gives priority to family reunification rationales for obtaining permanent residency compared to employment-based objectives, making the US' permanent residency policy tilted towards lower-skilled groups relative to those of other advanced countries. That said, temporary visas allow many skilled migrants into the United States for work, who then queue for permanent residency and are allowed to stay in the country until their case is finalized. Moreover, the United States derives advantages from the demand for high-skilled migration to the United States. Hunt (2011) compares different US entry routes and finds subsequent productivity and innovativeness to be highest for those entering directly for work or advanced schooling categories.

When it comes to talented foreigners, a number of countries not only remove restrictive visa regimes, but implement recruiting programs. Chile has received a lot of attention for its Start-up Chile program that pays foreign entrepreneurs to spend six months in the country as an effort to build global skill connections and a mini-Chilean "diaspora." Malaysia literally rolled out the red carpet at its airports in special lines as part of the Residence Pass Talent program (discussed in Del Carpio et al. 2015). Canada has been very active in targeting skilled migrants who are denied or frustrated by the H-1B visa system in the United States, even taking out ads on billboards in the United States to attract such migrants. The impact of these recruiting programs depends upon perspective. Effective design can yield measureable growth from the perspective of an individual country, with Start-up Chile for example now supporting 200-250 new ventures per year and Chile having launched sister programs based upon the success. The other perspective, however, is that these localized wins tend to be "drops in the bucket" compared to aggregate trends noted earlier like the steep concentration of high-skilled migration towards Anglo-Saxon countries.

Finally, countries also differ in the degree to which they can realistically reform their migration structures (Papademetriou and Sumption 2013; National Academies 2016). Some smaller and nimbler countries, like Singapore, can engage in "immigration engineering," in which policies are re-calibrated frequently based upon market conditions and public preferences. The US political structure, by contrast, seems to allow a once-in-a-decade type of reform to skilled migration policies. For example, H-1B reforms are often discussed, and economists frequently propose many alternatives (e.g., raise/lower the cap, price/auction the visas, etc.) to raise efficiency. Yet, the last major change was in the early 2000s, and the current annual visa caps were set in 2004, mainly because a number of leading political leaders have taken the stance that $\mathrm{H}-1 \mathrm{~B}$ reforms can only be considered in the context of comprehensive immigration reform. 


\section{Conclusions}

Looking forward, we believe skilled migration and the integration of global labor markets for high-skilled occupations will continue their march forward. There are natural limits to these forces, but escalating real estate prices and high-skilled wages in key clusters like London, New York, Hong Kong, and Silicon Valley indicate skilled migration won't be waning anytime soon. It is sometimes suggested that video conferencing, on-line labor markets, and other uses of communications technology can mitigate the need for talent flows and physical proximity. The evidence thus far is to the contrary, instead emphasizing how the new tools complement global movements instead of substituting for them.

While overall patterns will likely remain similar, different forms of high-skilled migration are likely to emerge and evolve. We expect that the skilled migration will increasingly involve shorter-durations and circular paths, for example, as opposed to one-way and long-duration experiences, due to greater global integration, lower transportation costs and rising standards of living outside of traditional advanced economies. The high-skilled members of the next generation appear to be less tied to any particular location or national identity, but instead have mentalities and connections that are much more global in nature than those of their predecessors. Moreover, the culture and outlook of companies and other employers, such as universities and football clubs, that employ the global talents are also becoming more global as their workforce is drawn from different corners of the world. ${ }^{16}$ Academics, business leaders and policymakers have only just started to grapple with these implications. The most successful individuals, employers and countries will be those that discern how to best navigate the current global labor markets and sidestep the government-imposed limitations on high-skilled immigration.

\footnotetext{
${ }^{16}$ Going back to the football example, Barcelona and Manchester United have 88 and 77 million members, respectively, in their Facebook fan clubs, significantly greater than the populations of their home cities (or even countries!).
} 


\section{References}

Agrawal, Ajay, Devesh Kapur, John McHale, and Alexander Oettl, "Brain Drain or Brain Bank? The Impact of Skilled Emigration on Poor-Country Innovation”, Journal of Urban Economics 69 (2011), 43-55.

Anderson, Stuart, “The Importance of International Students to America”, National Foundation for American Policy Brief (2013).

Amir, Rabah, and Malgorzata Knauff, "Ranking Economics Departments Worldwide on the Basis of PhD Placement”, Review of Economics and Statistics 90 (2008), 185-190.

Arslan, Cansin, Jean-Christophe Dumont, Zovanga Kone, Yasser Moullan, Çaglar Özden, Christopher Parsons and Theodora Xenogiani, "A New Profile of Migrants in the Aftermath of the Recent Economic Crisis”, OECD Social, Employment and Migration Working Paper 160 (2014).

Artuç, Erhan, Frederic Docquier, Çaglar Özden, and Christopher Parsons, "A Global Assessment of Human Capital Mobility: The Role of non-OECD Destinations”, World Development (2015).

Artuç, Erhan, and Çaglar Özden, “Transit Migration: All Roads Lead to America”, Economic Journal (2016), forthcoming.

Aydemir, Abdurrahman, and Chris Robinson, “Global Labor Markets, Return and Onward Migration”, Canadian Journal of Economics 41:4 (2008), 1285-1311.

Bandiera, Oriana, Imran Rasul, and Martina Viarengo, "The Making of Modern America: Migratory Flows in the Age of Mass Migration”, Journal of Development Economics 102 (2013), 23-47.

Beine, Michel, Frédéric Docquier, and Hillel Rapoport, "Measuring International Skilled Migration: A New Database Controlling for Age of Entry”, $\quad$ World Bank Economic Review 21:2 (2007), 249254.

Bhagwati, Jagdish, “Taxing the Brain Drain”, Challenge 19:3 (1976), 34-48.

Bijwaard, Govert, “Immigrant Migration Dynamics Model for The Netherlands”, Journal of Population Economics 23 (2010), 1213-1247.

Bijwaard, Govert, Christian Schluter, and Jackline Wahba, “The Impact of Labor Market Dynamics on the Return-Migration of Immigrants”, Review of Economics and Statistics 96 (2014), 483-494.

Bijwaard, Govert, and Jackline Wahba, “Do High-Income or Low-Income Immigrants Leave Faster?”, Journal of Development Economics 108 (2014), 54-68.

Borjas, George, “Self-Selection and the Earnings of Immigrants”, American Economic Review 77 (1987), 531-553.

Borjas, George, Labor Economics. 6th ed. (Boston, MA: McGraw-Hill/Irwin, 2012).

Borjas, George, and Kirk Doran, "The Collapse of the Soviet Union and the Productivity of American Mathematicians”, Quarterly Journal of Economics 127:3 (2012), 1143-1203.

Bosetti, Valentina, Cristina Cattaneo, and Elena Verdolini, "Migration of Skilled Workers and Innovation: A European Perspective”, Working Paper (2013).

Bound, John, Breno Braga, Joseph Golden, and Gaurav Khanna, "Recruitment of Foreigners in the Market for Computer Scientists in the United States”, Journal of Labor Economics 33:S1 (2015a), S187-S223.

Bound, John, Murat Demirci, Gaurav Khanna, and Sarah Turner, "Finishing Degrees and Finding Jobs: US Higher Education and the Flow of Foreign IT Workers", Innovation Policy and the Economy 15:1 (2015b), 27-72. 
Branstetter, Lee, Guangwei Li, and Francisco Veloso, “The Rise of International Co-invention”, in Adam Jaffe and Benjamin Jones (eds.) The Changing Frontier: Rethinking Science and Innovation Policy (Chicago, IL: University of Chicago Press, 2015), 135-168.

Breschi, Stefano, Francesco Lissoni, and Ernest Miguelez, "Foreign Inventors in the US: Testing for Diaspora and Brain Gain Effects”, CReAM Discussion Paper Series No. 1509 (2015).

Breschi, Stefano, Francesco Lissoni, and Gianluca Tarasconi, “Inventor Data for Research on Migration and Innovation: A Survey and a Pilot”, WIPO Economic Research Working Paper No. 17 (2014).

Clemens, Michael, "Economics and Emigration: Trillion-Dollar Bills on the Sidewalk?”, Journal of Economic Perspectives 25:3 (2011), 83-106.

Clemens, Michael, "Why Do Programmers Earn More in Houston than Hyderabad? Evidence from Randomized Processing of U.S. Visas”, American Economic Review Papers \& Proceedings 103:3 (2013), 198-202.

Czaika, Mathias and Christopher Parsons, “The Gravity of High-Skilled Migration Policies”, IMI Working Paper Series No. 110 (2015), Oxford: International Migration Institute.

Del Carpio, Ximena, Çaglar Özden, Mauro Testaverde, Mohamed Marouani, Bjorn Nilsson, and Mathis Wagner, "Foreign Workers in Malaysia: Labor Market and Firm Level Analysis," Malaysian Journal of Economic Studies 52:1 (2015), 1-19.

Docquier, Frédéric, Lindsay Lowell, and Abdeslam Marfouk, “A Gendered Assessment of Highly Skilled Emigration”, Population and Development Review 35:2 (2009), 297-322.

Docquier, Frédéric, and Elisabetta Lodigiani, "Skilled Migration and Business Networks", Open Economies Review 21:4 (2010), 565-588.

Docquier, Frédéric, and Hillel Rapoport, “Globalization, Brain Drain, and Development”, Journal of Economic Literature 50:3 (2012), 681-730.

Doran, Kirk, Alexander Gelber, and Adam Isen, "The Effects of High-skilled Immigration Policy on Firms: Evidence from Visa Lotteries”, NBER Working Paper 20668 (2014).

Dustmann, Christian, Samuel Bentolila, and Riccardo Faini, "Return Migration: The European Experience”, Economic Policy 11: 22 (1996), 213-250.

Dustmann, Christian, and Yoram Weiss, "Return Migration: Theory and Empirical Evidence from the UK”, British Journal of Industrial Relations 45:2 (2007), 236-256.

Finn, Michael, “Stay Rates of Foreign Doctorate Recipients from U.S. Universities, 2005”, Oak Ridge Institute for Science and Education Report (2007).

Foley, C. Fritz, and William Kerr, "Ethnic Innovation and U.S. Multinational Firm Activity”, Management Science 59:7 (2013), 1529-1544.

Franzoni, Chiara, Giuseppe Scellato, and Paula Stephan, "Foreign Born Scientists: Mobility Patterns for Sixteen Countries”, NBER Working Paper 18067 (2012).

Freeman, Richard, and Wei Huang, “China’s 'Great Leap Forward’ in Science and Engineering”, in Aldo Geuna (ed.), Global Mobility of Research Scientists: The Economics of Who Goes Where and Why (Elsevier, 2015).

Gaule, Patrick, "Who Comes Back and When? Return Migration Decisions of Academic Scientists", Economics Letters 124:3 (2014), 461-464.

Ghosh, Anirban, Anna Maria Mayda, and Francesc Ortega, “The Impact of Skilled Migration on FirmLevel Productivity: An Investigation of Publicly Traded U.S. Firms”, Working Paper (2016). 
Gibson, John, and David McKenzie, "The Microeconomic Determinants of Emigration and Return Migration of the Best and the Brightest: Evidence from the Pacific”, IZA Working Paper 3926 (2009).

Grogger, Jeffrey, and Gordon Hanson, “The Scale and Selectivity of Foreign Born Ph.D. Recipients in the U.S.”, American Economic Review Papers and Proceedings 103:3 (2013), 189-192.

Gundel, Sebastian, and Heiko Peters, "What Determines the Duration of Stay of Immigrants in Germany? Evidence from a Longitudinal Duration Analysis”, International Journal of Social Economics 35: 11 (2008), 769-782.

Harvey, William, "British and Indian Scientists in Boston Considering Returning to Their Home Countries”, Population, Space and Place 15 (2009), 493-508.

Hicks, John, The Theory of Wages (London: Macmillian, 1932).

Hira, Ron, “The H-1B and L-1 Visa programs: Out of Control”, EPI Briefing Paper 280 (2010).

Hovhannisyan, Nune, and Wolfgang Keller, “International Business Travel: An Engine of Innovation?”, Journal of Economic Growth 20:1 (2015), 75-104.

Hunt, Jennifer, "Which Immigrants are Most Innovative and Entrepreneurial? Distinctions by Entry Visa”, Journal of Labor Economics 29:3 (2011), 417-457.

Hunt, Jennifer, and Marjolaine Gauthier-Loiselle, “How Much Does Immigration Boost Innovation?”, American Economic Journal: Macroeconomics 2:2 (2010), 31-56.

Jones, Chad, “R\&D-Based Models of Economic Growth”, Journal of Political Economy 103 (1995), 759784.

Kahn, Shulamit, and Megan MacGarvie, “How Important is U.S. Location for Research in Science?”, Review of Economics and Statistics 98:2 (2016): 397-414.

Kapur, Devesh, and John McHale, Give Us Your Best and Brightest: The Global Hunt for Talent and Its Impact on the Developing World (Centre for Global Development, 2005).

Kato, Takao, and Chad Sparber, “Quotas and Quality: The Effect of H-1B Visa Restrictions on the Pool of Prospective Undergraduate Students from Abroad”, Review of Economics and Statistics 95:1 (2013), 109-126.

Kerr, Sari, and William Kerr, “Global Collaborative Patents”, Economic Journal (2015), forthcoming.

Kerr, Sari, William Kerr, and William Lincoln, "Firms and the Economics of Skilled Immigration”, Innovation Policy and the Economy 15:1 (2015a), 115-152.

Kerr, Sari, William Kerr, and William Lincoln, "Skilled Immigration and the Employment Structures of U.S. Firms”, Journal of Labor Economics 33:S1 (2015b), S147-S186.

Kerr, William, "Ethnic Scientific Communities and International Technology Diffusion”, Review of Economics and Statistics 90:3 (2008), 518-537.

Kerr, William, “U.S. High-Skilled Immigration, Innovation, and Entrepreneurship: Empirical Approaches and Evidence”, in Carsten Fink and Ernest Miguelez (eds.) The International Mobility of Talent and Innovation - New Evidence and Policy Implications (Cambridge, UK: Cambridge University Press, 2016), forthcoming.

Kerr, William, and William Lincoln, "The Supply Side of Innovation: H-1B Visa Reforms and U.S. Ethnic Invention”, Journal of Labor Economics 28:3 (2010), 473-508.

Kugler, Maurice, and Hillel Rapoport, “Migration, FDI and the Margins of Trade”, Working Paper (2011).

Matloff, Norman, "On the Need for Reform of the H-1B Non-Immigrant Work Visa in Computer-Related Occupations”, University of Michigan Journal of Law Reform 36:4 (2003), 815-914. 
Miguelez, Ernest, “Inventor Diasporas and the Internationalization of Technology”, American Economic Review, forthcoming. CREAM Discussion Paper Series 25/14 (2016).

Miguelez, Ernest, and Carsten Fink, "Measuring the International Mobility of Inventors: A New Database”, World Intellectual Property Organization Working Paper 8 (2013).

Moretti, Enrico, The New Geography of Jobs (Houghton Mifflin Harcourt, 2012).

Moser, Petra, Alessandra Voena, and Fabian Waldinger, “German Jewish Émigrés and U.S. Invention”, American Economic Review 104:10 (2014), 3222-3255.

Nathan, Max. "Same Difference? Minority Ethnic Inventors, Diversity and Innovation in the UK", Journal of Economic Geography 15:1 (2015), 129-168.

National Academies, Immigration Policy and the Search for Skilled Workers (2016).

Nejad, Maryam Naghsh, and Andrew Young, "Female Brain Drains and Women's Rights Gaps: A Gravity Model Analysis of Bilateral Migration Flows,” IZA Discussion Paper 8067 (2014).

OECD, “International Migration Outlook: SOPEMI - 2008 Edition”, OECD, Paris (2008).

OECD, “OECD Factbook 2013: Economic, Environmental and Social Statistics”, OECD, Paris (2013).

Özden, Çaglar, Christopher Parsons, Maurice Schiff, and Terrie Walmsley, "Where on Earth is Everybody? The Evolution of Global Bilateral Migration, 1960-2000”, World Bank Economic Review 25 (2011), 12-56.

Özden, Çaglar, and David Phillips, "What Really is Brain Drain? Location of Birth, Education and Migration Dynamics of African Doctors”, KNOMAD Working Paper (2015)

Ozgen, Ceren, Peter Nijkamp, and Jacques Poot, “Immigration and Innovation in European Regions”, IZA Working Paper 5676 (2011).

Papademetriou, Demetrios, and Madeline Sumption, Attracting and Selecting from the Global Talent Pool - Policy Challenges (Washington, D.C.: Migration Policy Institute, 2013).

Parrotta, Pierpaolo, Dario Pozzoli, and Mariola Pytlikova, "The Nexus between Labor Diversity and Firm's Innovation”, Journal of Population Economics 27:2 (2014): 303-364.

Parsons, Christopher, and Alan Winters, “International Migration, Trade and Aid: A Survey”, in Robert E.B. Lucas (ed.) International Handbook on Migration and Economic Development (Edward Elgar, 2014).

Peri, Giovanni, Kevin Shih, and Chad Sparber, "STEM Workers, H-1B Visas and Productivity in US Cities", Journal of Labor Economics 33:S1 (2015), S225-S255.

Peri, Giovanni, and Chad Sparber, "Highly-Educated Immigrants and Native Occupational Choice”, Industrial Relations 50:3 (2011), 385-411.

Pohl, Carsten, “Return Migration of Low- and High-Skilled Immigrants from Germany”, IFO Institute for Economic Research (2006).

Rosen, Sherwin, “The Economics of Superstars”, American Economic Review 71:5 (1981), 845-858.

Rosenzweig, Mark, “Global Wage Differences and International Student Flows”, Brookings Trade Forum Global Labor Markets (2006), 57-96.

Roy, A.D., "Some Thoughts on the Distribution of Earnings", Oxford Economic Papers 3:2 (1951), 135146.

Saxenian, AnnaLee, The New Argonauts (Cambridge, MA: Harvard University Press, 2006).

Saxenian, AnnaLee, with Yasuyuki Motoyama and Xiaohong Quan, Local and Global Networks of Immigrant Professionals in Silicon Valley (San Francisco, CA: Public Policy Institute of California, 2002). 
Silicon Valley Competitiveness and Innovation Report, A Dashboard and Policy Scorecard for a Shared Agenda of Prosperity and Opportunity, (Collaborative Economics, 2015).

Stephan, Paula, “The I's Have It: Immigration and Innovation, the Perspective from Academe”, in Josh Lerner and Scott Stern (eds.) Innovation Policy and the Economy (Cambridge, MA: MIT Press, 2010).

Stephan, Paula, and Sharon Levin, "Exceptional Contributions to US Science by the Foreign-Born and Foreign-Educated”, Population Research and Policy Review 20:1 (2001), 59-79.

Stuen, Eric, Ahmed Mobarak, and Keith Maskus, "Skilled Immigration and Innovation: Evidence from Enrollment Fluctuations in U.S. Doctoral Programs”, Economic Journal 122:565 (2012), 11431176.

Wasmer, Etienne, Paul Fredriksson, Ana Lamo, Julian Messina, and Giovanni Peri, "The Macroeconomics of Education in Europe” in Brunello, Garibaldi, and Wasmer (eds.) Education and Training in Europe (Oxford: Oxford University Press, 2007).

Weinberg, Bruce, "Developing Science: Scientific Performance and Brain Drains in the Developing World”, Journal of Development Economics 95:1 (2011), 95-104. 
Figure 1: Migrant Stocks in OECD Countries in 1990 and 2010

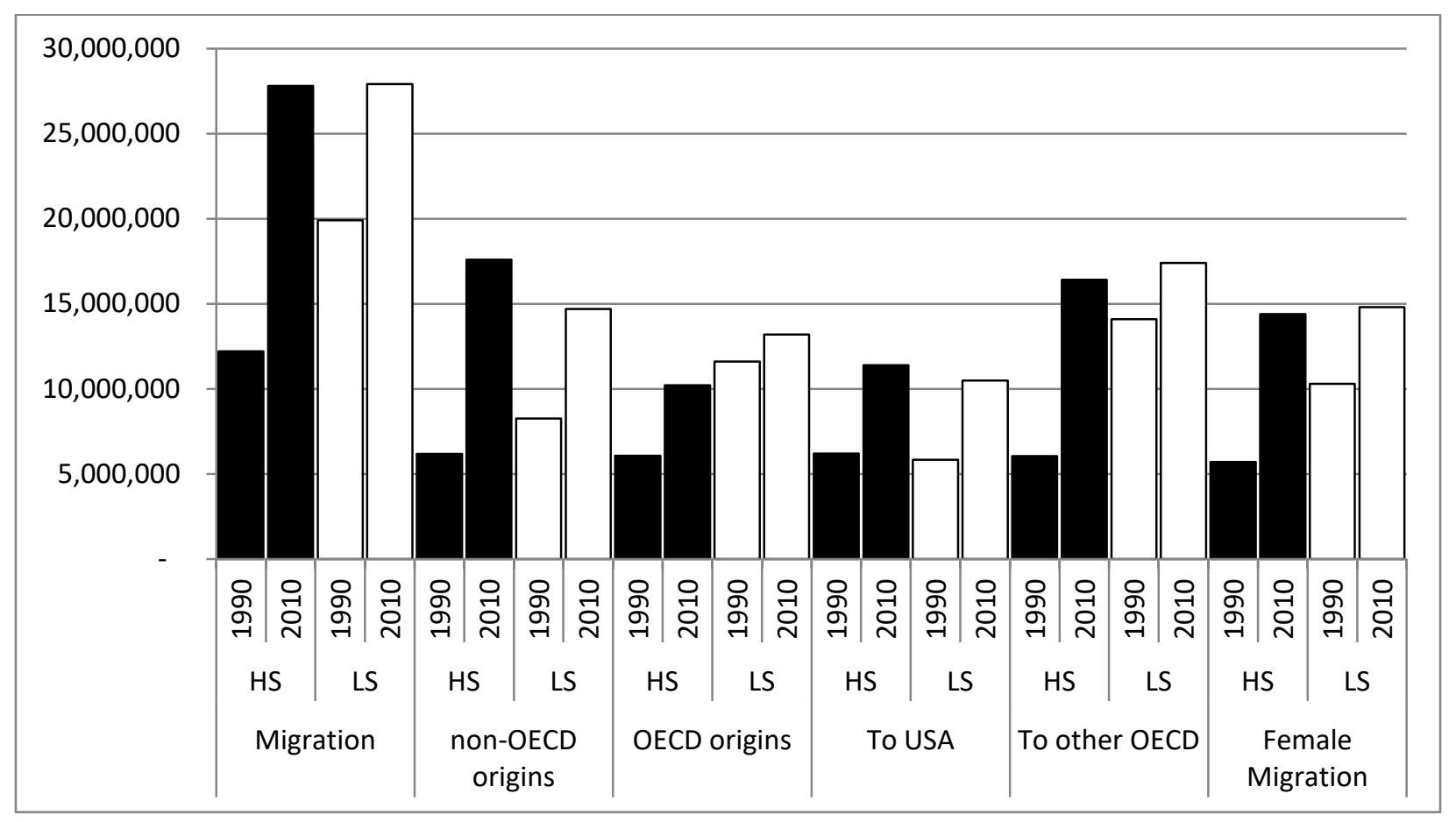

Notes: Migration patterns taken from Database on Immigrants in OECD Countries and Docquier et al. (2009). High-skilled workers are defined as those with at least one year of tertiary education. The data presented cover people of working age (25+) and pertain to 29 OECD members with consistent data from 1990 and 2010. 


\section{Figure 2: Cumulative Distribution of High-Skilled Immigration and Emigration, 2010}

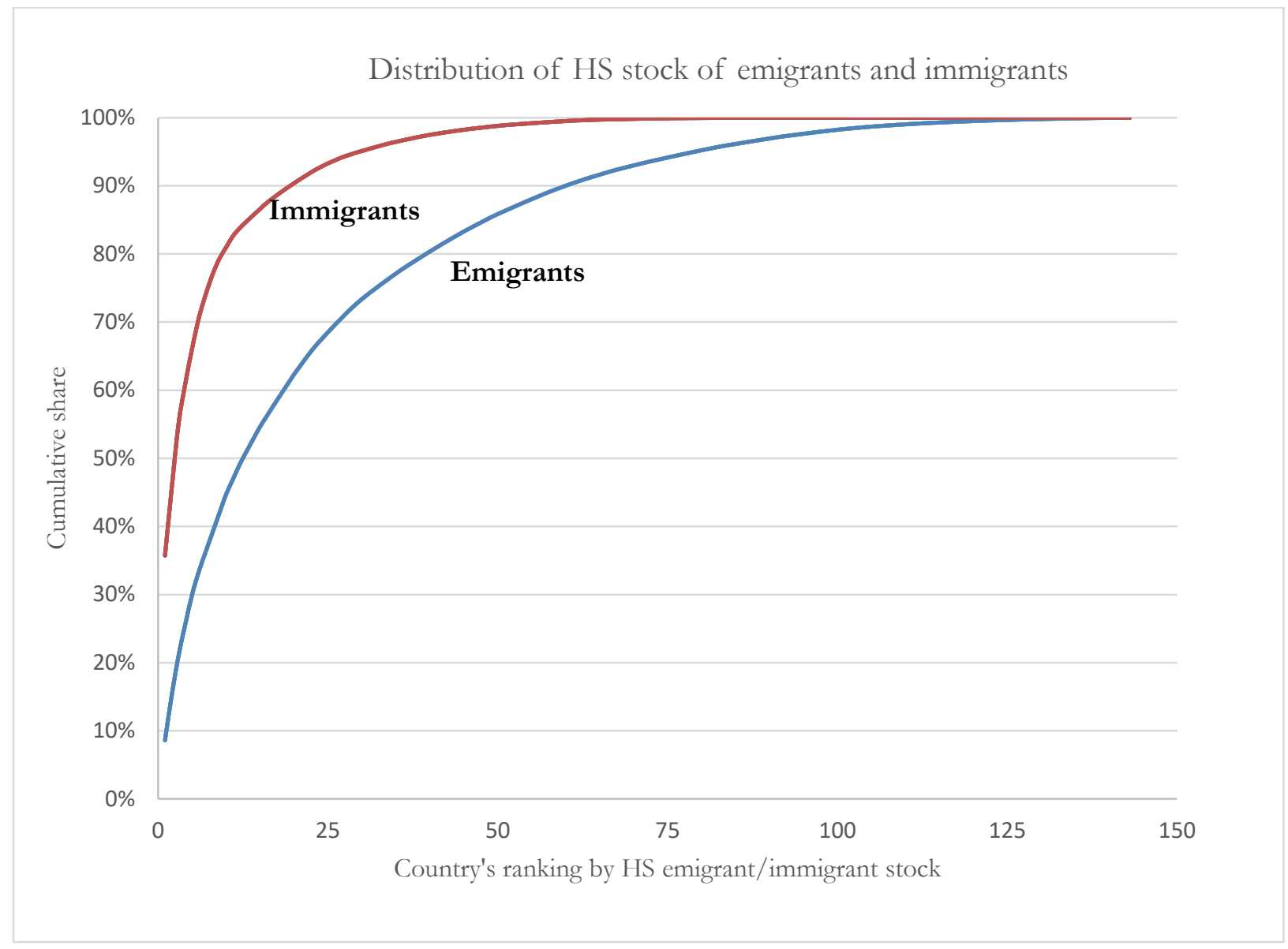

Notes: Data are from Database on Immigrants in OECD Countries (DIOC) and non-OECD Countries (DIOC-E). High-skilled workers are defined as those with at least one year of tertiary education. The data presented cover people of working age (25+). Countries are ranked according to their share of total high-skilled immigrant inflows and outflows, respectively. These distributions demonstrate that emigration flows have a much wider base relative to the moreconcentrated set of immigrant destinations. 


\section{Figure 3: Emigration Rates of High-Skilled Workers by Population, 2010}

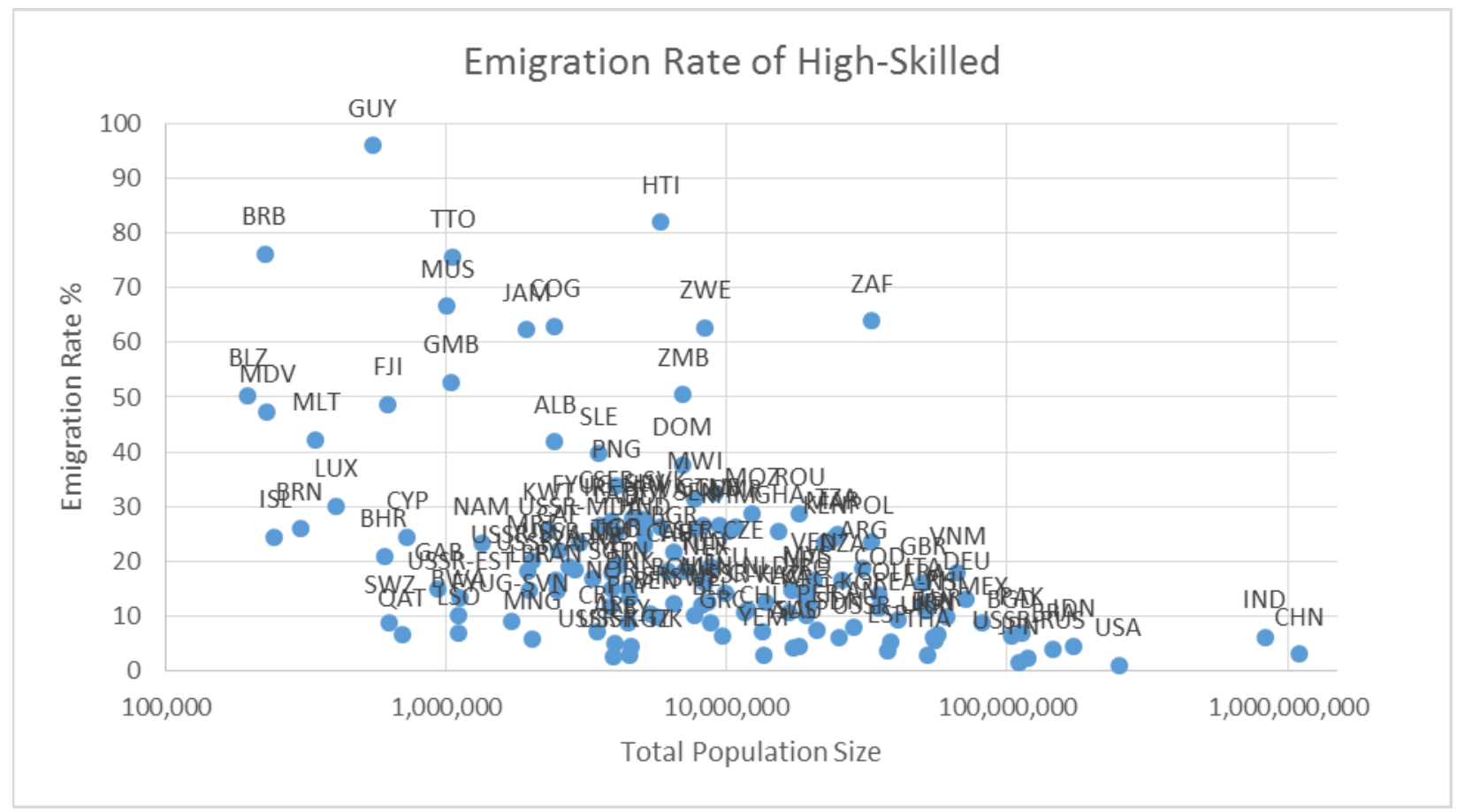

Notes: Emigration data are from Database on Immigrants in OECD Countries (DIOC) and nonOECD Countries (DIOC-E). High-skilled workers are defined as those with at least one year of tertiary education. The data cover people of working age $(25+)$ and pertain to over 200 origin countries. Population data are also for people of working age (25+) and taken from the World Development Indicators of the World Bank accessible at databank.worldbank.org/wdi. 
Figure 4: WIPO Migration of Inventors, 2000-2010

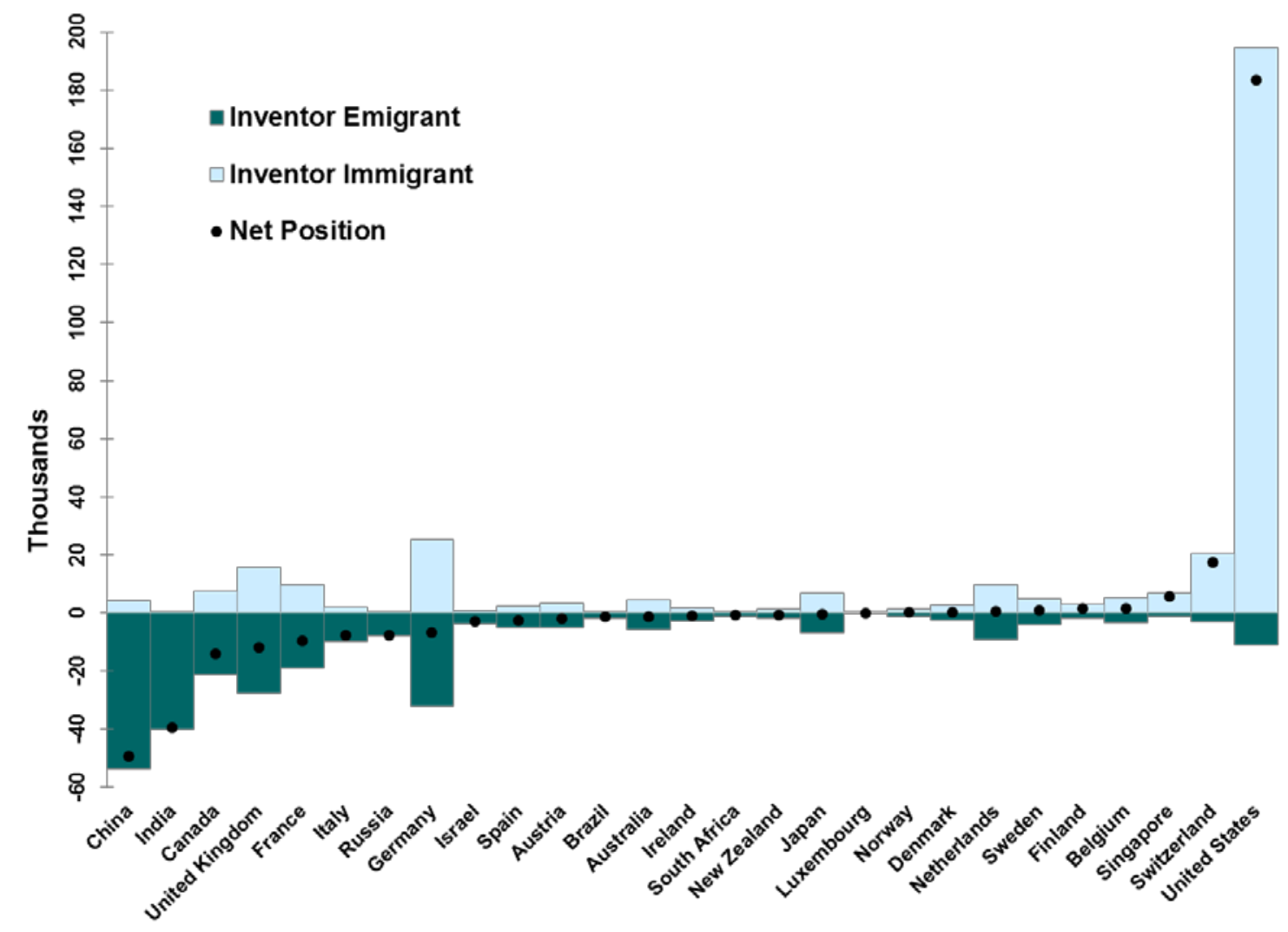

Notes: Migration patterns for inventors taken from the World Intellectual Property Organization (WIPO) database and Miguelez and Fink (2013). 